\title{
University grades and time of day of instruction
}

\author{
NICHOLAS F. SKINNER \\ King's College, University of Western Ontario, London, Ontario, Canada
}

\begin{abstract}
The hypothesis that performance should be comparable in university day and night courses was not supported. Mean grades in morning classes were significantly lower than those for the afternoon and evening. A number of possible contributors to this discrepancy are discussed. Consideration is given to the need to reexamine previous findings that "morning" and "evening" types are normally distributed.
\end{abstract}

Lay's (1912) discovery of a relationship between learning and time of day was supported by Kleitman's (1963) assertion that 'the existence of distinct 'morning' and 'evening' types is ... an everyday observation, among students particularly, some preferring to study late at night and sleep late in the morning, while others like to go to bed early and study early in the morning'" (p. 161). Thus, the present study tested the hypothesis that student performance should be comparable in university courses offered during the day or at night.

Official records were obtained for all courses $(\mathrm{N}=173$ ) taught at a small liberal arts college in 1982-1983. As summarized in Table 1, mean grades in afternoon and evening classes did not differ appreciably. However, marks in morning courses were significantly lower than those for both the afternoon and evening $(t=2.33, \mathrm{p}<.05$, twotailed, and $t=2.52, p<.02$, two-tailed, respectively).

Several factors may have contributed to the higher grades in afternoon and evening classes. (1) Repeated classes: For courses in which the same individual taught two sections (first in the morning and then again in the afternoon or evening), average marks were lower in the morning sections by a ratio of more than $3: 1$, suggesting that in the afternoon or evening, instructors may have improved upon their earlier presentations; however, given that the differences between morning and afternoon/evening means in these repeat classes-which comprised only about one-quarter of the sample-were not statistically significant, the impact of such a "practice effect" was presumably slight. (2) Honors courses: Only mild support existed for the possibility that the difference could be due to a preponderance of honors courses (which require students to obtain at least $70 \%$ to meet degree progression regulations); that is, honors courses constituted only $14 \%$ of morning offerings and $22 \%$ of afternoon/evening courses. (3) Class length: Compared with the morning classes $(22 \%)$, nearly three times as many

\footnotetext{
The author acknowledges financial support from the King's College Research Grants Committee. Requests for reprints should be sent to the author at King's College, 266 Epworth Avenue, London, Ontario, Canada N6A 2M3.
}

Table 1

Average Marks in Three Course Levels as a Function of Time of Day of Instruction

\begin{tabular}{|c|c|c|c|c|c|c|}
\hline \multirow[b]{3}{*}{ Level of Courses } & \multicolumn{6}{|c|}{ Average Marks (in Percent) } \\
\hline & \multicolumn{2}{|c|}{$\begin{array}{l}\text { Morning } \\
\text { Courses }\end{array}$} & \multicolumn{2}{|c|}{$\begin{array}{c}\text { Afternoon } \\
\text { Courses } \\
\end{array}$} & \multicolumn{2}{|c|}{$\begin{array}{l}\text { Evening } \\
\text { Courses }\end{array}$} \\
\hline & $\mathrm{n}$ & $\%$ & $\mathrm{n}$ & $\%$ & $\mathrm{n}$ & $\%$ \\
\hline Year 1 & 25 & 68.4 & 19 & 67.7 & 13 & 69.1 \\
\hline General (Years 2-4) & 25 & 67.8 & 17 & 70.7 & 12 & 71.3 \\
\hline Honors (Years 2-4) & 24 & 73.5 & 31 & 75.1 & 7 & 80.1 \\
\hline Overall & 74 & 68.9 & 67 & 71.9 & 32 & 72.3 \\
\hline
\end{tabular}

afternoon and evening classes (59\%) met once a week for an extended period of time; thus, despite the fact that "the rule of distributed practice is one of the most general in all learning' (Morgan, 1961, p. 224), it may be that a single weekly class of 3 -h duration is pedagogically more efficient (and encourages higher attendance) than three 1-h sessions.

In conclusion, it is reasonable to assume that, whenever possible, a course will be selected because it is taught and examined at a time of day that is most compatible with a particular student's circadian rhythm. Thus, to the extent that the above suggestions may not provide a complete explanation for the higher grades found in afternoon and evening classes, it remains for future research to reexamine Freeman and Hovland's (1934) venerable claim that "morning" and "evening" students are normally distributed in the population.

\section{REFERENCES}

Freeman, G. L., \& Hovland, C. I. (1934). Diurnal variations in performance and related physiological processes. Psychological Bulletin, 31, 777-799.

Kleitman, N. (1963). Sleep and wakefulness. Chicago: University of Chicago.

LAY, W. A. (1912). Ueber das Morgen und Abend lernen [On morning and evening learning]. Zeitschrift für die Erforschung der Behandlung jugendlichen Schwachsinns, 5, 285-292.

Morgan, C. T. (1961). Introduction to psychology (2nd ed.). New York: McGraw-Hill.

(Manuscript received for publication October 31, 1984.) 